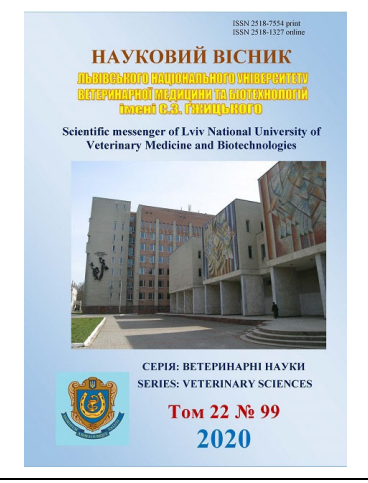

\author{
Науковий вісник Аьвівського національного університету \\ ветеринарної медицини та біотехнологій імені С.3. Гжицького. \\ Серія: Ветеринарні науки \\ Scientific Messenger of Lviv National University \\ of Veterinary Medicine and Biotechnologies. \\ Series: Veterinary sciences
}

UDC 636.7:616.995.42

\title{
The effectiveness of methods for laboratory diagnosis of otodectosis in dogs
}

\author{
L. Korchan, A. Zamaziy \\ Poltava State Agrarian Academy, Poltava, Ukraine
}

Article info

Received 05.09.2020 Received in revised form 05.10 .2020

Accepted 06.10.2020

Poltava State Agrarian Academy, Skovorody Str., 1/3,

Poltava, 36003, Ukraine. Tel.: +38-095-158-85-78

E-mail:korchanl98@gmail.com
Korchan, L., \& Zamaziy, A. (2020). The effectiveness of methods for laboratory diagnosis of otodectosis in dogs. Scientific Messenger of Lviv National University of Veterinary Medicine and Biotechnologies. Series: Veterinary sciences, 22(99), 58-62. doi: 10.32718/nvlvet9909

Otodectosis in domestic dogs is caused by ectoparasites of the species Otodectes cynotis (Hering, 1838), which parasitize on the inner surface of the auricles, the external auditory canal and the eardrum. The invasion is accompanied by severe itching, otitis, anxiety of animals, and sometimes - their death due to complications. The effectiveness of measures to combat otodectosis in dogs largely depends on the correct and accurate diagnosis of the invasion. At the same time, existing laboratory methods have different diagnostic efficiency. The aim of the study was to establish the effectiveness of mortal and vital methods of lifelong diagnosis of otodectosis in dogs. The effectiveness of modern methods of laboratory diagnosis of live and dead ticks of the species $O$. cynotis in dogs has been established. The most effective methods have been identified, the use of which will improve the quality of acarological research. Studies have shown that the most effective method of mortal methods was A. M. Titarenko, where a mixture of $50 \%$ aqueous solution of glycerin, dimethyl sulfoxide and $10 \%$ sodium hydroxide solution (the intensity of the invasion was 5.4 specimens of mites) was used as an illuminator. This method exceeded the intensity of invasion using the compressor method -2 times (2.7 specimens of mites, $P<0.001)$, the flotation method -1.2 times $(4.5$ specimens of mites). At the same time, the flotation method for otodectosis in dogs was 1.7 times more effective $(P<0.001)$ than the use of the compressor method. Of the vital methods of laboratory diagnosis of otodectosis in dogs, the most effective was the method using vegetable oil as a scraper clarifier, the intensity of the invasion was 5.9 copies. ticks. The use of this technique in terms of the number of detected otodectes exceeded the method of A.V. Alfimova (influence of elevated temperature) - 2.1 times (2.8 specimens of mites, $P<0.001$ ) and the method of M.G. Khatin (centrifugation under the influence of elevated). temperature) -1.3 times (4.6 specimens of mites, $P<0.001$ ). In addition, the congratulatory method of $M$. G. Khatin in the diagnosis of otodectosis was 1.6 times more effective $(P<0.001)$ than the method of A. V. Alfimova.

Key words: ectoparasites, Otodectes cynotis, dogs, laboratory diagnostics, diagnostic efficiency.

\section{Ефективність методів лабораторної діагностики отодектозу собак}

\author{
Л. М. Корчан, А. А. Замазій
}

Полтавська державна аграрна академія, м. Полтава, Украӥна

\begin{abstract}
Отодектоз у домашніх собак викликають ектопаразити виду Otodectes cynotis (Hering, 1838), щзо паразитують на внутрішній поверхні вушних раковин, зовнішньому слуховому проході та барабанній перетинці. Інвазія супроводжується сильним свербежем, отитом, занепокоєнням тварин, іноді - ї загибеллю внаслідок ускладнень. Результативність заходів боротьби з отодектозом собак значною мірою залежить від правильного й точного діагностування інвазії. Водночас, існуючі лабораторні методи мають різну діагностичну ефективність. Метою роботи було встановити ефективність мортальних та вітальних методів зажиттєвої діагностики отодектозу в собак. Встановлено ефективність сучасних методів лабораторної діагностики виявлення живих та мертвих кліщів виду O. супотіs у собак. Визначено найефективніші методики, застосування яких дозволить підвищити якість проведення акарологічних досліджень. Проведеними дослідженнями встановлено, щзо з мортальних методів найбільи ефективним виявився метод А. М. Титаренко, де як просвітлювач матеріалу використовували суміш $50 \%$ водного розчину глічерину, диметилсульфоксиду і $10 \%$ розчину їкого натру (інтенсивність інвазії становила 5,4 екз. клішів). Цей метод перевищував показники
\end{abstract}


інтенсивності інвазії за використання компресорного методу - у 2 рази (2,7 екз. кліщів, Р < 0,001), флотаційного методу - у 1,2 разу (4,5 екз. кліщів). Водночас флотаційний метод за отодектозу собак виявився ефективнішим у 1,7 разу (P < 0,001), ніж застосування компресорного методу. 3 вітальних методів лабораторної діагностики отодектозу в собак найбільи ефективним виявився спосіб із застосуванням рослинної олії як просвітлювача зіскрібків, інтенсивність інвазії становила 5,9 екз. клішів. Використання даної методики за показниками кількості виявлених отодектесів перевищувало спосіб А. В. Алфімової (вплив підвищеної температури) - у 2,1 разу (2,8 екз. кліщів, $P<0$,001) та спосіб М. Г. Хатіна (иентрифугування за впливу підвищеної температури) - y 1,3 разу (4,6 екз. кліщуів, $P<0$,001). Також вітальний спосіб М. Г. Хатіна при діагностиці отодектозу був ефективнішим у 1,6 разу ( $P<0,001)$, ніж спосіб А. В. Алфімової.

Ключові слова: ектопаразити, Otodectes cynоtis, собаки, лабораторна діагностика, діагностична ефективність.

\section{Вступ}

Акарози - це велика група інвазійних захворювань, що викликаються акариформними кліщами. У природі їх налічується близько 10000 видів. Одним 3 ектопаразитів, що має важливе медико-ветеринарне значення, є кліщ виду Otodectes cynotis (Radford, 1943; Lopez, 1993; Lohse et al., 2002). Значне поширення даного збудника обумовлюється збільшенням поголів'я домашніх собак і котів, збільшенням популяції безпритульних тварин, утриманням домашніх м'ясоїдних на низькому рівні ветеринарного обслуговування (Tonn, 1961; Chee et al., 2008; Lefkaditis et al., 2009; Fanelli et al., 2020).

Результативність заходів боротьби з отодектозом собак значною мірою залежить від правильного й точного діагностування інвазії. Загальновідомо, що 3 метою дослідження зіскрібків зі шкіри тварини на наявність O. cynotis застосовують мортальні та вітальні методи. Мортальні методики спрямовані на виявлення мертвих кліщів, а вітальні методи - живих, що має значення для оцінки ефективності проведеного лікування (Kraft et al., 1988; Radlinsky, 2016; Combarros et al., 2019).

Існує багато мортальних методів для виявлення отодектесів. Це методи, які грунтуються на обробці відібраного від тварини матеріалу розчинами, що згубно діють на кліщів. Водночас відбувається просвітлення зіскрібку та його розм'якшення. 3 найвідоміших - методи із застосуванням 5-10\% розчину $\mathrm{KOH}$ чи $\mathrm{NaOH}$; флотаційний метод; різні модифікації 3 додаванням диметилсульфоксиду, гліцерину, із застосуванням центрифугування (Foley, 1991; Wall \& Shearer, 2001; Soulsby, 2005).

Багато науковців пропонують різноманітні вітальні методики виявлення живих кліщів. 3 них найвідоміші способи, які засновані на чутливості акариформних кліщів до підвищення температури. Внаслідок цього паразити починають активно рухатися у теплій рідині або вони активно виповзають із матеріалу, що робить їх помітними (Medvedev, 1999; Tretijakov et al., 2006). Інші автори удосконалювали вітальні методи шляхом додавання до матеріалу різних речовин, які гарантують високий ступінь його просвітлення та водночас не діють згубно на кліщів. Так, було запропоновано додавання до відібраного зіскрібку зі шкіри вазеліново-диметилсульфоксидної суміші, де вазелін зменшує трансепідермальну втрату вологи, а диметилсульфоксид - сприяє кращому проникненню вазеліну в кірочки (Ponomarenko, 2004). Окремі автори визначили, що відбір матеріалу із зовнішнього слухово- го проходу та внутрішньої поверхні вушної раковини за допомогою стерильної гігроскопічної вати, змоченої 3 \% розчином перекису водню, дозволяє витрачати мінімум часу для досліджень, а також зумовлює кращій вихід кліщів 3 кірочок, ніж загальновідомі вітальні методи (Manzhos \& Lavrinenko, 2008).

Отже, незважаючи на значну кількість запропонованих науковцями вітальних та мортальних методів лабораторної діагностики акарозів собак, викликаних акариформними кліщами, на сьогодні немає загальновизнаного способу, який би забезпечував високу діагностичну ефективність незалежно від збудника інвазіі. Тому $є$ необхідність встановлення ефективності методів зажиттєвої діагностики за конкретної інвазії м'ясоїдних тварин з метою подальшої рекомендації у виробництво.

У зв'язку з вищенаведеним, метою роботи було встановити ефективність мортальних та вітальних методів зажиттєвої діагностики отодектозу в собак.

\section{Матеріали і методи досліджень}

Роботу виконували упродовж 2020 р. на базі лабораторії кафедри паразитології та ветеринарносанітарної експертизи, а також лабораторії кафедри інфекційної патології, гігієни, санітарії та біобезпеки Полтавської державної аграрної академії. 3 метою вивчення діагностичної ефективності зажиттєвої діагностики отодектозу в собак порівнювали загальновідомі вітальні методи - за А. В. Алфімовою (з використанням термостату), за В. О. Свстаф'євою і В. Ф. Галатом (з використанням рослинної оліі), за М. Г. Хатіним (з використанням центрифугування) та мортальні методи - компресорне дослідження (3 використанням розчину їдкого натру), флотаційний спосіб (з використанням гіпертонічного розчину аміачної селітри), за А. М. Титаренко (з використанням гліцерину, диметилсульфоксиду та розчину їдкого натру).

Зіскрібки відбирали з шкіри внутрішньої поверхні вушних раковин площею $6 \mathrm{~cm}^{2}$. Враховували показники інтенсивності інвазії (II, екз. кліщів). Всього проведено 120 досліджень зіскрібків зі шкіри хворих на отодектоз собак.

Математичний аналіз отриманих даних проводили 3 використанням програми Statistica 10 (StatSoft Inc., США). Розраховували стандартні відхилення (SD) i середні значення (х). Достовірність відмінностей середніх величин визначали за допомогою методики однофакторного дисперсійного аналізу, використо- 
вуючи критерій Фішера. Значення $\mathrm{P}<0,05$ вважали достовірним.

\section{Результати та їх обговорення}

Проведеними дослідженнями встановлено, що при застосуванні як мортальних, так і вітальних методів діагностики у досліджуваних собак виявляли кліщів виду Otodectes cynotis. Однак їх діагностична ефективність достатньо різнилася. Так, з мортальних методів найефективнішим виявився метод А. М. Титаренко,

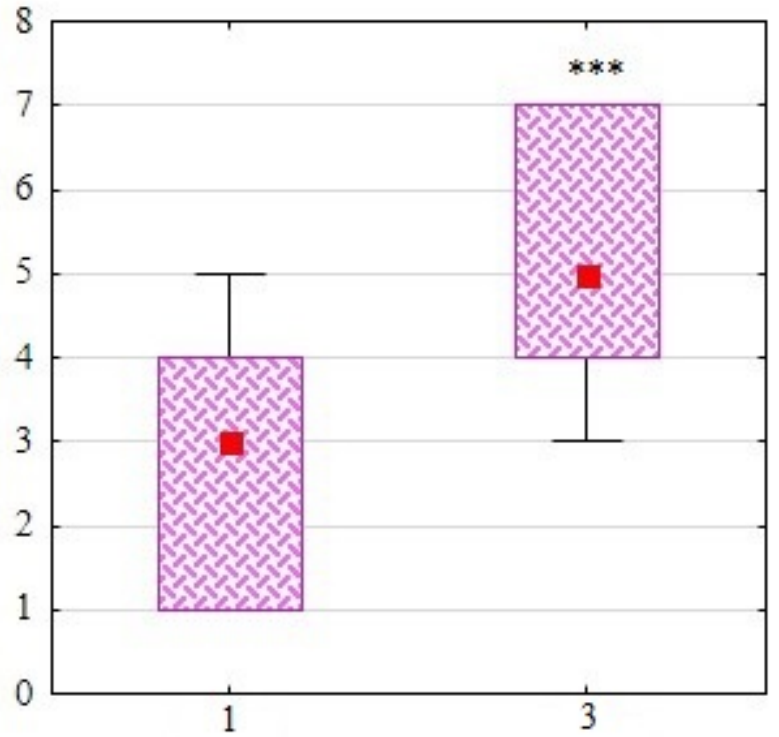

a

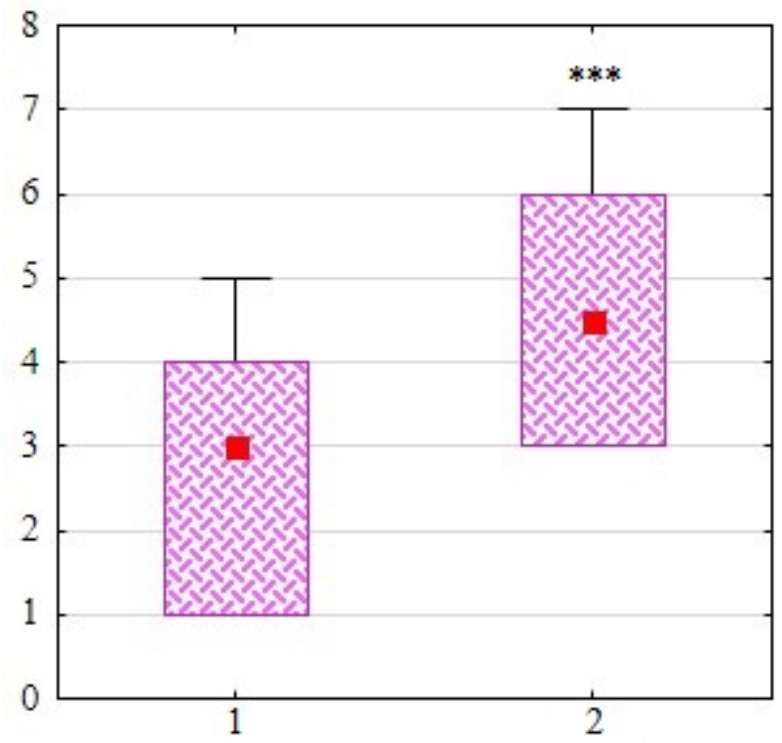

де як просвітлювач матеріалу використовували суміш 50 \% водного розчину гліцерину, диметилсульфоксиду і $10 \%$ розчину їдкого натру $(1: 1: 1)$. Інтенсивність інвазії становила 5,40 $\pm 1,31$ екз. кліщів, що у 2 рази $(\mathrm{P}<0,001)$ більше, ніж за використання компресорного методу (II $-2,70 \pm 1,45$ екз.) та 1,2 разу більше, ніж за використання флотаційного методу $(4,56 \pm 1,50$ екз.) (рис. 1 a, б). Водночас флотаційний метод за отодектозу собак виявився ефективнішим у 1,7 разу $(\mathrm{P}<0,001)$, ніж застосування компресорного методу (рис. 1 с).

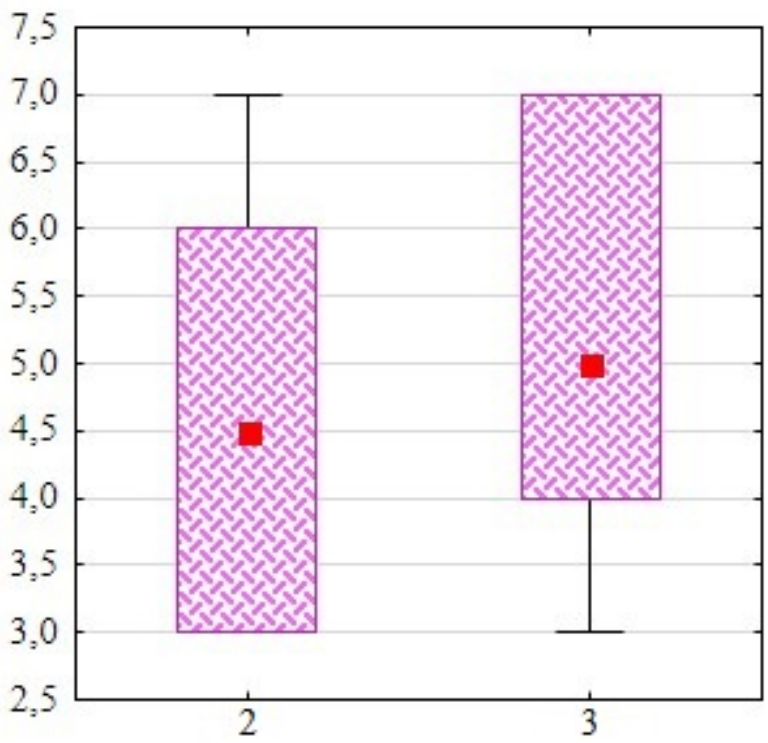

б

Рис. 1. Порівняльна ефективність мортальних методів лабораторної діагностики отодектозу собак $(\mathrm{n}=20)$ : 1 - метод компресорного дослідження, 2 - флотаційний метод, 3 - метод за А. М. Титаренко; *** $\mathrm{P}<0,001$

При порівнянні ефективності вітальних методів діагностики отодектозу собак виявлено, що найбільші значення інтенсивності інвазії $(5,95 \pm 1,00$ екз. кліщів) отримано за умов застосування способу В. О. Свстаф'євої і В. Ф. Галата із використанням рослинної олії в як просвітлювача зіскрібків. Викори- стання даної методики за показниками кількості виявлених отодектесів перевищувало спосіб А. В. Алфімової (вплив підвищеної температури) - у 2,1 разу ( $\mathrm{P}<0,001$, II $-2,85 \pm 1,66$ екз. кліщів) та спосіб М. Г. Хатіна (центрифугування за впливу підвищеної температури) - у 1,3 разу $(\mathrm{P}<0,001$, II $-4,65 \pm$ 
1,04 екз. кліщів) (рис. 2 a, б). Водночас вітальний спосіб М. Г. Хатіна при діагностиці отодектозу був
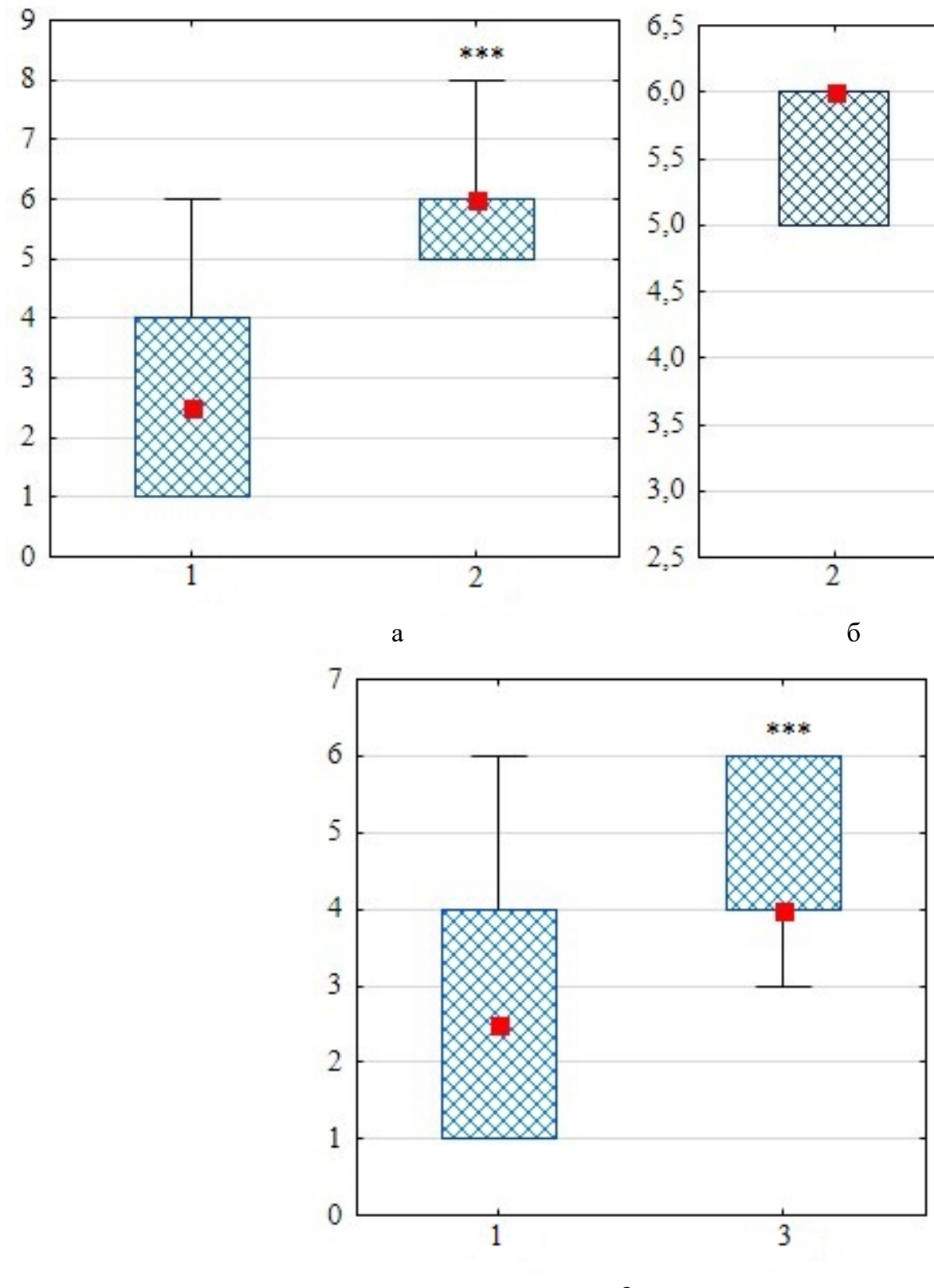

ефективнішим у 1,6 разу $(\mathrm{P}<0,001)$, ніж спосіб А. В. Алфімової (рис. 2 с).

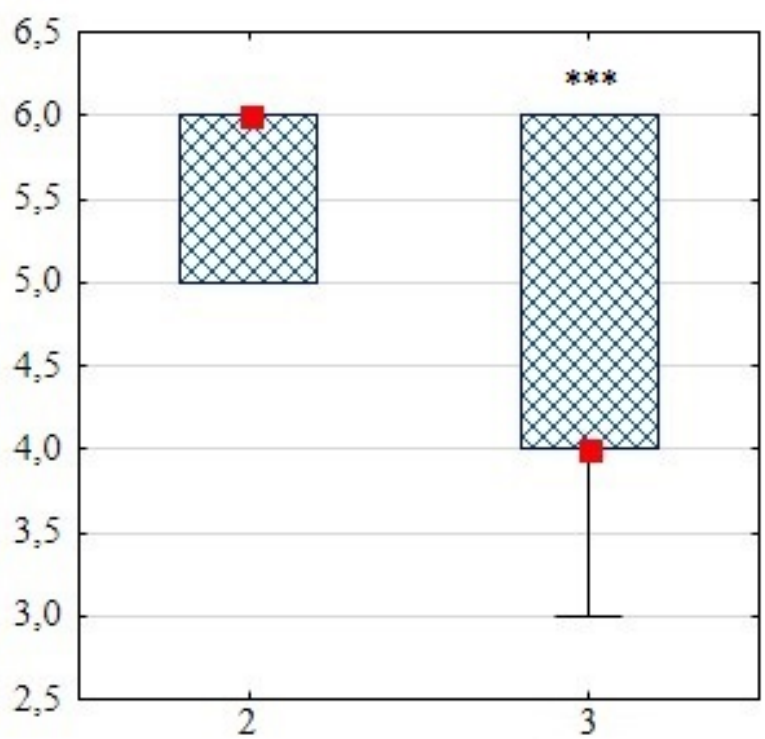

6

Рис. 2. Порівняльна ефективність вітальних методів лабораторної діагностики отодектозу собак $(\mathrm{n}=20)$ : 1 - метод за А. В. Алфімовою, 2 - метод із застосуванням рослинної олї̈ (за В. О. Свстаф’євою і В. Ф. Галатом), 3 - метод за М. Г. Хатіним; *** $\mathrm{P}<0,001$

Науковці більшості країн світу вказують на широке розповсюдження отодектозу серед м'ясоїдних тварин, у тому числі серед популяції домашніх собак і котів (Chee et al., 2008; Lefkaditis et al., 2009; Fanelli et al., 2020). Тому застосування ефективних, точних i зручних у використанні методів лабораторної діагностики цієї інвазії є актуальним напрямом досліджень. За результатами проведених досліджень встановлено, що загальновідомі методи виявлення як живих кліщів, так і мертвих є достатніми для постановки діагнозу. Водночас їхня ефективність значно відрізняється. Так, при порівняні мортальних способів, які за методикою різнилися складом речовини, що забезпечувала просвітлення відібраного матеріалу, ефективнішим ви- явися метод А. М. Титаренко (із використанням суміші гліцерину, диметилсульфоксиду, $10 \%$ розчину їдкого натру). Меншу ефективність показав компресорний метод (із використанням $10 \%$ розчину їдкого натру). Найменшу ефективність встановлено при застосуванні флотаційного методу (із використанням гіпертонічного розчину аміачної селітри). Водночас, при порівнянні вітальних методів найефективнішим виявися метод В. О. Свстаф'євої і В. Ф. Галата (із використанням рослинної олії). Менші показники ефективності отримано при застосуванні методу М. Г. Хатіна (із використанням центрифугування та впливу підвищеної температури) і найменшу ефективність показав метод А. В. Алфімової (із використан- 
ням впливу підвищеної температури). Схожі дані отримали науковці, які встановили, що додавання до зіскрібку рослинної олії має більшу діагностичну ефективність за саркоптозу свиней, ніж метод А. В. Алфімової (Yevstafieva \& Aranchij, 2002). Про низьку ефективність методу А. В. Алфімової при діагностиці саркоптозу, отодектозу і демодекозу собак свідчать наукові дані, отримані В. О. Євстаф'євою та К. А. Гаврик (Yevstafieva \& Gavryk. 2014).

Отже, застосування більш чутливих та ефективних методів лабораторної діагностики за отодектозу собак дозволить своєчасно встановити діагноз, підвищити ефективність лікувальних заходів, а також запобігти ускладненню хвороби.

\section{Висновки}

Одним із найефективніших мортальних методів лабораторної діагностики отодектозу в собак є метод А. М. Титаренко, ефективність якого перевищує результативність способів за використання: компресорного методу - у 2 рази $(\mathrm{P}<0,001)$ та флотаційного методу - у 1,2 разу. Найефективнішим вітальним методом лабораторної діагностики отодектозу в собак виявився метод В. О. Свстаф’євої і В. Ф. Галата, що перевищував результативність методу А. В. Алфімової - у 2,1 разу $(\mathrm{P}<0,001)$ та методу М. Г. Хатіна - у 1,3 разу $(\mathrm{P}<0,001)$.

Перспективи подальших досліджень. Проведені дослідження обумовлюють необхідність встановлення ефективності сучасних інсектоакарицидних препаратів за отодектозу собак.

\section{References}

Chee, J. H., Kwon, J. K., Cho, H. S., Cho, K. O., Lee, Y. J., Abd El-Aty, A. M., \& Shin, S. S. (2008). A survey of ectoparasite infestations in stray dogs of Gwang-ju City, Republic of Korea. Korean Journal of Parasitology, 46(1), 23-27. doi: 10.3347/kjp.2008.46.1.23.

Combarros, D., Boncea, A. M., Brément, T., Bourdeau, P., \& Bruet, V. (2019). Comparison of three methods for the diagnosis of otoacariasis due to Otodectes cynotis in dogs and cats. Veterinary Dermatology, 30(4), 334-e96. doi: 10.1111/vde.12753.

Fanelli, A., Doménech, G., Alonso, F., MartínezCarrasco, F., Tizzani, P., \& Martínez-Carrasco, C. (2020). Otodectes cynotis in urban and peri-urban semi-arid areas: a widespread parasite in the cat population. Journal of Parasitic Diseases, 44(2), 481485. doi: 10.1007/s12639-020-01215-7.

Foley, R. H. (1991). Parasitic mites of dogs and cats. Compendium on Continuing Education for the Practicing Veterinarian, 13, 783-800.
Kraft, W., Kraiss-Gothe, A., \& Gothe, R. (1988). Otodectes cynotis infestation of dogs and cats: biology of the agent, epidemiology, pathogenesis and diagnosis and case description of generalized mange in dogs. Tierarztliche Praxis, 16(4), 409-415. URL: https://pubmed.ncbi.nlm.nih.gov/3065982.

Lefkaditis, M. A., Koukeri, S. E., \& Mihalca, A. D. (2009). Prevalence and intensity of Otodectes cynotis in kittens from Thessaloniki area, Greece. Veterinary Parasitology, 163(4), 374-375. doi: 10.1016/j.vetpar.2009.04.027.

Lohse, J., Rinder, H., Gothe, R., \& Zahler, M. (2002). Validity of species status of the parasitic mite Otodectes cynotis. Medical and Veterinary Entomology, 16(2), 133-138. doi: 10.1046/j.13652915.2002.00355.x.

Lopez, R. A. (1993). Of mites and man. Journal of the American Veterinary Medical Association, 203(5), 606607. URL: https://pubmed.ncbi.nlm.nih.gov/8407518.

Manzhos, O. F., \& Lavrinenko, I. V. (2008). Porivnjal'na harakterystyka metodiv diagnostyky otodektozu m'jasoi'dnyh. Problemy Zooinzhenerii' ta Veterynarnoi' Medycyny, 16(41), 68-71 (in Ukrainian).

Medvedev, K. S. (1999). Bolezni kozhi sobak i koshek. Vima, Kiev (in Russian).

Ponomarenko, O. V. (2004). Udoskonalennja laboratornoi' diagnostyky akaryformnyh klishhiv. Veterynarna Medycyna, 84, 588-590 (in Ukrainian).

Radford, C. (1943). Genera and species of parasitic mites (Acarina). Parasitology, 35(1-2), 58-81. doi: 10.1017/S0031182000011938.

Radlinsky, M. G. (2016). Advances in otoscopy. The veterinary clinics of North America. Small Animal Practice, 46(1), 171-179. doi: 10.1016/j.cvsm.2015.08.006.

Soulsby, E. J. L. (2005). Helminths, arthropods and protozoa of domestic animals; 7th ed. Reed Elsevier Publishing. Delhi.

Tonn, R. J. (1961). Studies on the ear mite Otodectes cynotis, including life cycle. Annals of the Entomological Society of America, 54(3), 416-421. doi: 10.1093/aesa/54.3.416.

Tretijakov, A. M., Evdokimov, P. I., \& Shabaev, V. A. (2006). Laboratornaja diagnostika parazitarnih zabolevanij zhivotnyh. Ulan-Udje (in Russian).

Wall, R., \& Shearer, D. (2001). Veterinary ectoparasites: biology, pathology and control. Wiley-Blackwell, Ames, Iowa.

Yevstafieva, V. O., \& Aranchij, S. V. (2002). Rekomendacii' po borot'bi ta profilaktyci sarkoptozu svynej. Poltava (in Ukrainian).

Yevstafieva, V. O., \& Gavryk, K. A. (2014). Udoskonalennja metodiv zazhyttjevoi' diagnostyky sarkoptozu, otodektozu ta demodekozu sobak. Visnyk Poltavs'koi' Derzhavnoi' Agrarnoi' Akademii', 4, 6264 (in Ukrainian). 